\title{
Sluggish Reactivity by a Nonheme Iron(IV)-Tosylimido Complex as Compared to its Oxo Analogue
}

DOI:

10.1039/DODT00018C

\section{Document Version}

Accepted author manuscript

Link to publication record in Manchester Research Explorer

\section{Citation for published version (APA):}

Mukherjee, G., Reinhard, F., Bagha, U. K., Sastri, C. V., \& De Visser, S. (2020). Sluggish Reactivity by a Nonheme Iron(IV)-Tosylimido Complex as Compared to its Oxo Analogue. Dalton Transactions.

https://doi.org/10.1039/D0DT00018C

\section{Published in:}

Dalton Transactions

\section{Citing this paper}

Please note that where the full-text provided on Manchester Research Explorer is the Author Accepted Manuscript or Proof version this may differ from the final Published version. If citing, it is advised that you check and use the publisher's definitive version.

\section{General rights}

Copyright and moral rights for the publications made accessible in the Research Explorer are retained by the authors and/or other copyright owners and it is a condition of accessing publications that users recognise and abide by the legal requirements associated with these rights.

\section{Takedown policy}

If you believe that this document breaches copyright please refer to the University of Manchester's Takedown Procedures [http://man.ac.uk/04Y6Bo] or contact uml.scholarlycommunications@manchester.ac.uk providing relevant details, so we can investigate your claim.

\section{OPEN ACCESS}




\title{
Sluggish Reactivity by a Nonheme Iron(IV)-Tosylimido Complex as Compared to its Oxo Analogue
}

Received 00th January 20xx, Accepted 00th January 20xx DOI: $10.1039 / x 0 x \times 00000 x$

\author{
Gourab Mukherjee, ${ }^{a}$ Fabián G. Cantú Reinhard, ${ }^{\text {b }}$ Umesh Kumar Bagha, ${ }^{a}$ Chivukula V. Sastri*a and \\ Sam P. de Visser*b
}

\begin{abstract}
High-valent iron-nitrido intermediates have been postulated as reactive intermediates in various enzymes, including the nitrogenases and the cytochromes P450, but so far few have been trapped and characterized. As little is known on their oxidative and spectroscopic properties, we decided to create biomimetic models of iron(IV)-imido complexes and compare their structure and reactivity with analogous iron(IV)-oxo systems. In this work we report the synthesis and spectroscopic characterization of a novel $\left[\mathrm{Fe}^{\mathrm{IV}}(\mathrm{NTS}) \text { (Bntpen) }\right]^{2+}$ complex $\left(\right.$ Bntpen $=\mathrm{N}^{1}$-benzyl- $\mathrm{N}^{1}, \mathrm{~N}^{2}, \mathrm{~N}^{2}$-tris (pyridine-2-ylmethyl)ethane-1,2diamine) and study its reactivity patterns with respect to hydrogen atom abstraction and nitrogen atom transfer reactions. The work is compared with analogous pentadentate ligand systems as well as with iron(IV)-oxo species with the same ligand features and highlights the differences in chemical properties and reactivity patterns. It is shown that the reactivity is dependent on the metal ligand system that affects the physico chemical properties of the oxidant such as the redox potential, which is the main driving force for the reaction mechanism with substrates.
\end{abstract}

\section{Introduction}

High-valent metal-oxo and metal-nitrido species are common intermediates in enzymes and are found in the catalytic cycles of several oxidases as well as in nitrogenases. ${ }^{1,2}$ Thus, in many of these oxygenases, the enzymes utilize molecular oxygen to create a high-valent nonheme iron(IV)-oxo or iron(IV)-oxo heme cation radical species as active oxidant. On the other hand, few enzymes use nitrogen to generate a high-valent iron(IV)-nitrido or -imido active species. Nevertheless, the latter has been proposed as an intermediate in nitrogenase: the enzyme that binds molecular nitrogen on a FeMo cluster containing seven iron and a molybdenum atom bridged by sulphides. ${ }^{2}$ The FeMo co-factor in nitrogenases reduces nitrogen to ammonia. The only other enzyme that is known to form a high-valent iron(IV)imido intermediate is the heme enzyme cytochrome P450 possibly as part of a substrate aziridation and imidation reaction of substrates. ${ }^{3}$

As these high-valent intermediates are short-lived they are difficult to trap and characterize and consequently few reports

\footnotetext{
a. Department of Chemistry, Indian Institute of Technology Guwahati, Assam 781039, India. Fax: +91-361-258-2349; E-mail: sastricv@iitg.ernet.in.

b. The Manchester Institute of Biotechnology and Department of Chemical Engineering and Analytical Science, The University of Manchester, 131 Princess Street, Manchester M1 7DN, United Kingdom. E-mail: sam.devisser@manchester.ac.uk.

Electronic Supplementary Information (ESI) available: Experimental and computational raw data, including Cartesian coordinates of optimized structures, absolute and relative energies and group spin densities and charges. See DOI: $10.1039 / x 0 \times x 00000 x$
}

on enzymatic nonheme iron(IV)-oxo intermediates are known, ${ }^{4}$ and even fewer on iron(IV)-nitrido. ${ }^{3}$ To gain insight into these short-lived enzymatic intermediates, many biomimetic models have been synthesized that have the active site features of the metal but lack the protein environment. ${ }^{5}$ Especially, a significant number of reports on biomimetic nonheme iron model systems containing a central iron(IV)-oxo species are known. ${ }^{6}$ On the other hand, on the analogous iron(IV)tosylimido or iron(IV)-nitrido species very few investigations have been reported. 7,8 The iron(IV)-tosylimido systems are interesting to study as their bulkier tail, as compared to iron(IV)oxo or iron(IV)-nitrido, makes the approach of crowded substrates difficult. However, the spectroscopic characterization of these iron(IV)-tosylimido species is also challenging.

Using the pentadentate N4Py ligand, i.e. N,N-bis(2pyridylmethyl)-N-bis(2-pyridyl) methyl amine (Scheme 1), the corresponding iron(IV)-oxo and iron(IV)-tosylimido oxidants were synthesized and trapped and characterized with a range of spectroscopic methods. ${ }^{8 a, 9}$ Over the past few years, effective perturbations in the equatorial ligand field of the N4Py ligand were induced to explore the second-coordination sphere effects on the reactivity of the iron(IV)-oxo species with substrates and its spectroscopic parameters. ${ }^{10}$ These N4Py derivatives ( $2^{\text {nd }}$ generation N4Py ligands) were shown not only to stabilize the iron(IV)-oxo species better, but also to drastically improve their catalytic efficiency. Unfortunately, for many of these N4Py derivatives the iron(IV)-imido moiety has been 
tested but due to additional bulk on the equatorial ligand field such exercises remained futile. Recently, Nam and co-workers have showcased the stabilization and reactivity of iron(V)tosylimido species with the anionic TAML (tetraamidomacrocyclic ligand) ligand, [ $\left.\mathrm{Fe}^{\mathrm{IV}}(\mathrm{NTS})(\mathrm{TAML})\right]$, which also offers a planar structure for the tosylimido group to sit upon. ${ }^{11}$ It was also pointed out that in the coordination sphere of the iron(IV)-NTs active species, apart from the relative positioning of the donor atoms, the nature and number of donor groups is also responsible for their relative stability. ${ }^{12}$

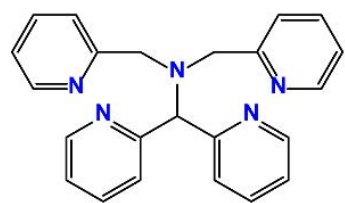

N4Py

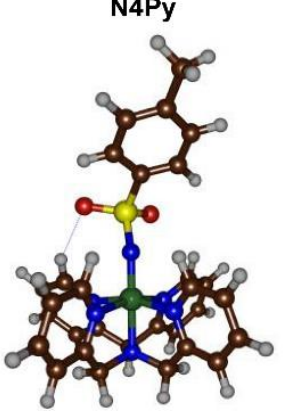

$\left[\mathrm{Fe}^{\mathrm{IV}}(\mathrm{NTs})(\mathrm{N} 4 \mathrm{Py})\right]^{2+}(2)$

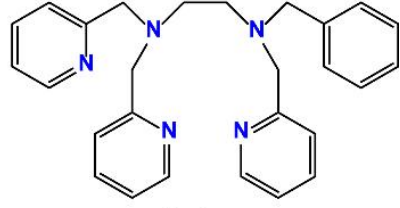

Bntpen

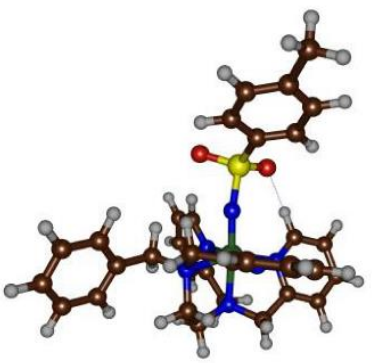

$\left[\mathrm{Fe}^{\mathrm{IV}}(\mathrm{NTs})(\text { Bntpen })\right]^{2+}(4)$
Scheme 1. Chemical structures of the ligands and $\left[\mathrm{Fe}^{\mathrm{IV}}(\mathrm{NTs})(\mathrm{N} 4 \mathrm{Py})\right]^{2+}(\mathbf{2})$ and $\left[\mathrm{Fe}^{\mathrm{IV}}(\mathrm{NTs})(\text { Bntpen })\right]^{2+}(\mathbf{4})$ complexes.

It was shown that the ligand architecture of N4Py affects the oxidant positioning as well as the substrate approach. Other fundamental properties like one-electron reduction potential and the reorganization energies in electron transfer (ET) along with a substantial change in reaction mechanism between iron(IV)-oxo and iron(IV)-imido complexes has been demonstrated by Vardhaman et al. ${ }^{13}$

Clearly, there are still many gaps in the understanding of ironimido, iron-nitrido and iron-oxo oxidants. To gain insight into the properties and reactivities of these biomimetic species, we synthesized $\quad\left[\mathrm{Fe}^{\mathrm{IV}}(\mathrm{NTs})(\text { Bntpen) }]^{2+}, \quad\left[\mathrm{Fe}^{\mathrm{IV}}(\mathrm{O})(\text { Bntpen) }]^{2+}\right.\right.$, $\left[\mathrm{Fe}^{\mathrm{IV}}(\mathrm{NTs})(\mathrm{N} 4 \mathrm{Py})\right]^{2+}$ and $\left[\mathrm{Fe}^{\mathrm{IV}}(\mathrm{O})(\mathrm{N} 4 \mathrm{Py})\right]^{2+}$. The studies show differences in spectroscopic and electronic properties based on the pentadentate ligand, but also the differences between iron(IV)-oxo and iron(IV)-imido are explored.

\section{Methods}

\section{Materials}

The solvents were dried using previously reported procedures and were distilled and stored under an argon atmosphere prior to use. ${ }^{14}$ All chemicals were obtained from Aldrich Chemical Co and were of the best available purity and used without further purification unless otherwise stated. Iodosylbenzene and $\mathrm{N}$ - tosyliminophenyliodinane were prepared following reported procedures. ${ }^{15}$ The ligand Bntpen was synthesized by using procedures from the literature. ${ }^{16}$ The ferrous complex [Fe"(Bntpen) $\left.\left(\mathrm{CH}_{3} \mathrm{CN}\right)\right](\mathrm{OTf})_{2}$ and its oxo derivative. i.e. $\left[\mathrm{Fe}^{\mathrm{IV}}(\mathrm{O})(\text { Bntpen) }]^{2+}\right.$, were synthesized inside a glove-box filled with argon as described previously. ${ }^{16,17}$ Similar procedures as for $\left[\mathrm{Fe}^{\mathrm{IV}}(\mathrm{NTs})(\mathrm{N} 4 \mathrm{Py})\right]^{2+}$ have been followed in this work to generate the iron(IV)-imido complex. ${ }^{9}$ Deuterated benzyl alcohol- $\left[D_{7}\right]$ was procured from Cambridge Isotope Laboratories Inc.

\section{Instrumentation}

UV/Vis spectra were recorded on an Agilent 8453 spectrophotometer equipped with either constant temperature circulating water bath or a liquid nitrogen cryostat (Unisoku) with a temperature controller. High-resolution electrospray ionization mass spectra (ESI-MS) of $\left[\mathrm{Fe}^{\mathrm{IV}}(\mathrm{O})(\text { Bntpen) }]^{2+}\right.$ and $\left[\mathrm{Fe}^{\mathrm{IV}} \text { (NTs)(Bntpen) }\right]^{2+}$ were recorded on a Waters (Micromass MS Technologies) Q-TOF Premier mass spectrometer by infusing pre-cooled $(233 \mathrm{~K})$ samples directly into the source at

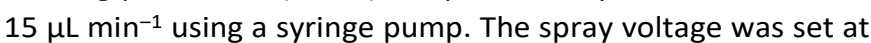
$2 \mathrm{kV}$ and the capillary temperature at $80^{\circ} \mathrm{C}$. Bruker Avance III HD 600 and $400 \mathrm{MHz}$ NMR spectrometers were used for recording NMR spectra using TMS as an internal standard. FTIR spectra were recorded on a Perkin Elmer FTIR spectrometer. Product analysis was performed using NMR spectroscopy and WATERS ACQUITY UPLC equipped with a variable wavelength UV-200 detector.

\section{Reaction Kinetics}

All reactions were run in a $10 \mathrm{~mm}$ path length UV/Vis cuvette by monitoring UV/Vis spectral changes of reaction solutions. The kinetics studies were performed under pseudo first-order conditions with excess substrate in dry acetonitrile. The reactions were monitored by following the decrease of the absorbance of the characteristic peaks as a function of time. The rate constants were determined by fitting the changes in absorbance of the intermediates under study. The reactions were run at least in triplicate and the data reported represents their average.

\section{Synthesis of $\left[\mathrm{Fe} "(\right.$ Bntpen $\left.)\left(\mathrm{CH}_{3} \mathrm{CN}\right)\right](\mathrm{OTf})_{2}$}

The ligand Bntpen (100 mg) was taken inside a dry glovebox and dissolved in $3 \mathrm{~mL}$ dichloromethane. $\mathrm{Fe}(\mathrm{OTf})_{2} \bullet 2 \mathrm{CH}_{3} \mathrm{CN}(1.2$ equivalents) was dissolved in $2 \mathrm{~mL}$ dichloromethane. The ligand solution was added dropwise to the stirred suspension of the ferrous salt solution. The reaction mixture was allowed to stir overnight and was then dried under vacuum. The resulting solid was washed with diethyl ether and dried in vacuo. The yellow powder was recrystallized with dichloromethane and diethyl ether to get $>90 \%$ yield.

\section{Synthesis of $\left[\mathrm{Fe}^{\mathrm{IV}} \text { (Bntpen)(NTs)](OTf) }\right)_{2}$}

The $\left[\mathrm{Fe}^{\mathrm{IV}}(\mathrm{NTs})(\text { Bntpen) }]^{2+}\right.$ complex was generated in situ by stirring the ferrous precursor complex with excess of the nitrene 
transfer reagent, PhINTs, inside a glovebox. Within $~ 30$ s the colour of the mixture changed to golden yellow. The resultant slurry was then filtered using $0.2 \mu \mathrm{m}$ PTFE syringe filters. The resultant filtrate was stored at $-40^{\circ} \mathrm{C}$ inside the anaerobic glove box for further use.

\section{Computation}

Density functional theory (DFT) was utilized using the unrestricted B3LYP density functional method for geometry optimizations and the mechanistic characterization of a series of [Fe ${ }^{\mathrm{IV}}(\mathrm{O})(\text { Bntpen) }]^{2+}$ and $\left[\mathrm{Fe}^{\mathrm{IV}}(\mathrm{NTs})(\text { Bntpen) }]^{2+}\right.$ complexes with two common substrates using procedures reported previously: dimethylsulfide (DMS) and 1,3-cyclohexadiene (CHD). ${ }^{18}$ Initial ground state geometry optimization searches were performed from two different conformations for each spin state: singlet, triplet or quintet. In all calculations an intermediate size basis set 6-31G* was employed on all atoms, except on the iron centre where LANL2DZ with electron core potential (ECP) was employed, basis set $\mathrm{BS} 1 .{ }^{19,20}$ Further (BS2) single point calculations were performed at the LACV3P+ level of theory (with core potential) on all atoms with the UB3LYP density functional. Finally, an implicit continuum polarized conductor model (CPCM) with acetonitrile as solvent model was included as an energy correction on all systems (BS2+Solvent). ${ }^{21}$ Further re-optimization of the $\left[\mathrm{Fe}^{\mathrm{IV}}(\mathrm{O})(\mathrm{N} 4 \mathrm{Py})\right]^{2+}$ and $\left[\mathrm{Fe}^{\mathrm{IV}}(\mathrm{NTs})(\mathrm{N} 4 \mathrm{Py})\right]^{2+}$ complexes and the reaction mechanisms was performed at the same level of theory for direct comparison. All geometry optimizations, frequencies and constraint geometry scans were run in Gaussian-09. ${ }^{22}$

Minimum-energy crossing points (MECPs) were calculated in Orca $^{23}$ at the same level of theory using the code developed by Harvey and co-workers. ${ }^{24}$

\section{Results and Discussion}

We started our study with synthesizing the basic ligand framework of $\mathrm{N}^{1}$-benzyl- $\mathrm{N}^{1}, \mathrm{~N}^{2}, \mathrm{~N}^{2}$-tris(pyridine-2-ylmethyl) ethane-1,2-diamine (Bntpen), ${ }^{16 \mathrm{~b}}$ which is a less symmetrical framework as compared to the N4Py ligand, see Scheme 1. A comparative reactivity study between $\left[\mathrm{Fe}^{\mathrm{IV}}(\mathrm{O})(\mathrm{N} 4 \mathrm{Py})\right]^{2+}$ and $\left[\mathrm{Fe}^{\mathrm{lV}}(\mathrm{O})(\text { Bntpen) }]^{2+}\right.$ complexes with various hydrocarbons was reported by Que and co-workers, where, the latter was known to be a better oxidant in terms of kinetic reaction rates. ${ }^{16 \mathrm{~b}}$ In particular, the iron(IV)-oxo complex, $\left[\mathrm{Fe}^{\mathrm{IV}}(\mathrm{O})(\text { Bntpen) }]^{2+}\right.$, was found to react faster with every organic substrate tested than $\left[\mathrm{Fe}^{\mathrm{IV}}(\mathrm{O})(\mathrm{N} 4 \mathrm{Py})\right]^{2+}$. When a detailed kinetic study was done between $\left[\mathrm{Fe}^{\mathrm{IV}}(\mathrm{NTS})(\mathrm{N} 4 \mathrm{Py})\right]^{2+}$ and $\left[\mathrm{Fe}^{\mathrm{IV}}(\mathrm{O})(\mathrm{N} 4 \mathrm{Py})\right]^{2+}$, the former showed faster reactivity in the sulfimidation reaction of thioanisole. However, the trend was found to be reversed for $\mathrm{C}-\mathrm{H}$ abstraction reactions instead. ${ }^{9}$ In order to find out how the ligand framework affects the reactivity patterns of iron(IV)tosylimido oxidants, we decided to do a comparative study between the $\left[\mathrm{Fe}^{\mathrm{IV}}(\mathrm{O})(\mathrm{N} 4 \mathrm{Py})\right]^{2+}(\mathbf{1}),\left[\mathrm{Fe}^{\mathrm{IV}}(\mathrm{NTS})(\mathrm{N} 4 \mathrm{Py})\right]^{2+}(\mathbf{2})$, $\left[\mathrm{Fe}^{\mathrm{IV}}(\mathrm{O})(\text { Bntpen) }]^{2+}(\mathbf{3})\right.$ and $\left[\mathrm{Fe}^{\mathrm{IV}}(\mathrm{NTs})(\text { Bntpen) }]^{2+}(\mathbf{4})\right.$. The work shows that the ligand framework affects substrate approach as well as the redox properties of the oxidant.
Complex $\mathbf{4}$ was synthesized using the nitrene transfer reagent PhINTs under an argon atmosphere. Similar to complex 2, the formation of 4 was identified by an intense LMCT band at 460 $\mathrm{nm}\left(\varepsilon=4100 \mathrm{M}^{-1} \mathrm{~cm}^{-1}\right)$ and a weaker band at $650 \mathrm{~nm}(\varepsilon=330$ $\mathrm{M}^{-1} \mathrm{~cm}^{-1}$ ) due to ligand field transitions characteristic for $S=1$ iron(IV) complexes, see Fig. 1a. Further characterization of the $\left[\mathrm{Fe}^{\mathrm{IV}}(\mathrm{NTs})(\text { Bntpen) }]^{2+},(\mathbf{4})\right.$, was done by electrospray ionization (ESI)-mass spectrometry (MS), proton NMR spectroscopy and Fourier transform infrared (FTIR) spectroscopy (see Electronic Supplementary Information for details). Unfortunately, under normal mass separation-conditions, unlike the case of $\left[\mathrm{Fe}^{\mathrm{IV}}(\mathrm{O})(\text { Bntpen)(OTf) }]^{+}\right.$, we did not manage to obtain a clear spectrum most probably due to thermal degradation of the intermediate under routine mass spectrometry conditions. This indicates weaker $\mathrm{Fe}=\mathrm{N}$ bonding in $\mathbf{4}$ than the $\mathrm{Fe}=\mathrm{O}$ bonding in $\mathbf{1}$ and 3, which is also evident from the corresponding stretch vibrations discussed later. Their thermal stability values at 298 $\mathrm{K}$ also reflect the same trend of bond strengths $\left(t_{1 / 2}\right.$ of $3=\sim 6 \mathrm{~h}$ while $t_{1 / 2}$ of $4=\sim 3 \mathrm{~h}$ ).

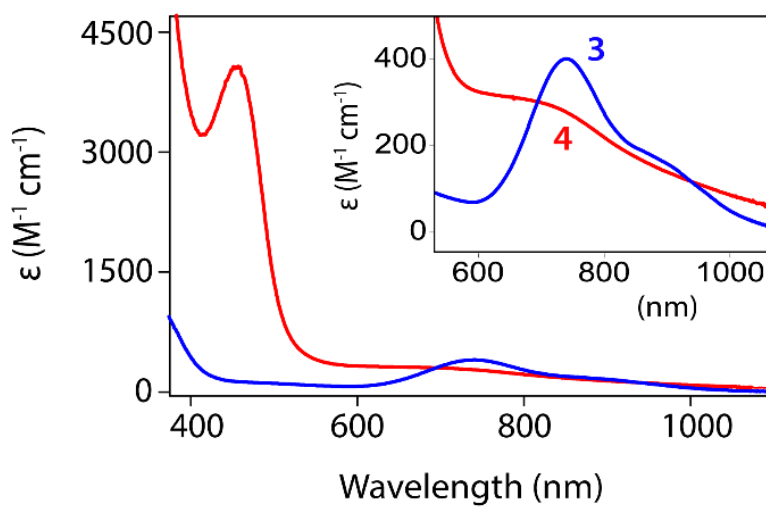

(a)

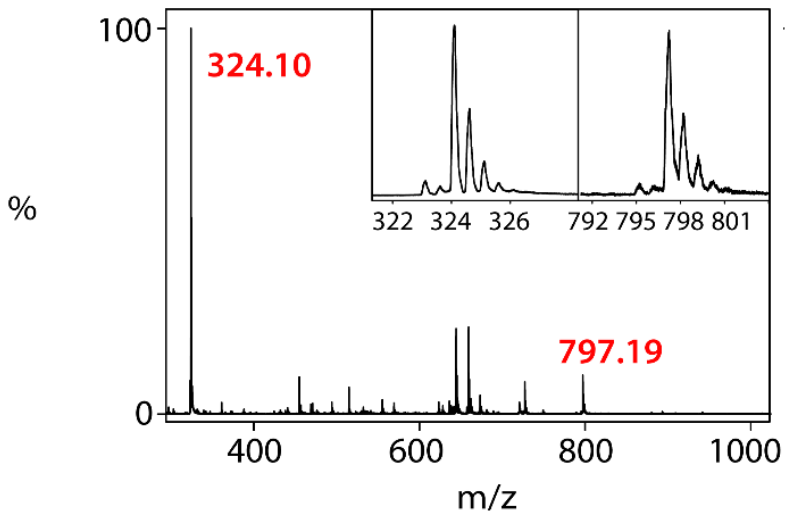

(b)

Fig. 1. (a) UV/Vis spectra of $1 \mathrm{mM}$ solutions of $\left[\mathrm{Fe}^{\mathrm{IV}}(\mathrm{O})(\text { Bntpen })\right]^{2+}(\mathbf{3}$, blue line) and [Fe' ${ }^{\mathrm{IV}}(\mathrm{NTs})$ (Bntpen)] ${ }^{2+}\left(\mathbf{4}\right.$, red line) in $\mathrm{CH}_{3} \mathrm{CN}$. (b) ESI-MS spectra of 4 in $\mathrm{CH}_{3} \mathrm{CN}$. Insets shows the isotopic distribution patterns for the peaks at $\mathrm{m} / \mathrm{z} 324.10$ and 797.19 .

However, the mass spectrum was obtained by infusing cold samples directly into the source (Fig. 1b). The spectrum shows a major peak at $\mathrm{m} / \mathrm{z} 324.10$ that can be attributed to the ion cluster $\left[\mathrm{Fe}^{\mathrm{IV}}\left(\right.\right.$ Bntpen)(NTs)] ${ }^{2+}$ (calculated $\mathrm{m} / \mathrm{z}$ 324.0979) and a smaller peak at $\mathrm{m} / \mathrm{z} 797.19$ corresponding to [Fe ${ }^{\mathrm{IV}}$ (Bntpen)(NTs)(OTf)] ${ }^{+}$(calculated $\mathrm{m} / \mathrm{z}$ 797.1490). Another peak at $\mathrm{m} / \mathrm{z} 644.16$ most likely can be assigned to traces of 
$\left[\mathrm{Fe}^{\mathrm{IV}}(\mathrm{O})(\text { Bntpen)(OTf) }]^{+}\right.$in the sample which thereby implicates the hydrolysis of the oxidant, PhINTs into PhIO (most probably this is due to the trace amount of water present in the solvent that enables oxidant exchange under ESI-MS conditions). Under normal conditions though, addition of water does not hydrolyse 4 into 3.

In the ${ }^{1} \mathrm{H}-\mathrm{NMR}$ spectrum, the $\mathrm{Fe}(\mathrm{II})$ complex [Fe(Bntpen)(OTf) $]^{2+}$ in $\mathrm{CDCl}_{3}$ shows a paramagnetic shift of peaks to higher $\delta$ values which is typical for an $S=2$ spin state on iron (Fig. S2, Electronic Supplementary Information). ${ }^{10 i, 25}$ By contrast, both the ferryl complexes, $\left[\mathrm{Fe}^{\mathrm{IV}}(\mathrm{O})(\text { Bntpen) }]^{2+}(\mathbf{3})\right.$ and $\left[\mathrm{Fe}^{\mathrm{IV}}(\mathrm{NTs})(\text { Bntpen) }]^{2+}(\mathbf{4})\right.$, give characteristic shifts in the NMR spectra of the $S=1 \mathrm{Fe}$ centres in $\mathrm{CD}_{3} \mathrm{CN}$ (Fig. S3, S4, Electronic Supplementary Information). ${ }^{7 \mathrm{~g}, 8 \mathrm{a}, 25}$ The overall NMR spectra for $\mathbf{3}$ and $\mathbf{4}$ are more complicated than those of $\mathbf{1}$ and $\mathbf{2}$ due to lack of symmetry in the Bntpen ligand framework as compared to the N4Py. ${ }^{10 i, 16 d, 25}$ In $\mathbf{3}$ and $\mathbf{4}$, there are pyridine rings both perpendicular and parallel to the $\mathrm{Fe}=\mathrm{X}$ axis $(\mathrm{X}=\mathrm{O}, \mathrm{N})$ rendering an uneven shift pattern due to unequal interactions of the pyridine rings with the $\mathrm{Fe}=\mathrm{X}$ core. ${ }^{16 \mathrm{~d}}$ The unique shift pattern of the pyridine $\beta$-protons to positive (downfield) and negative (upfield) $\delta$ values infers that the Fe centre is oxidized to the +4 oxidation state, which is linked to the terminal oxidant being oxo or NTs (see Electronic Supplementary Information).

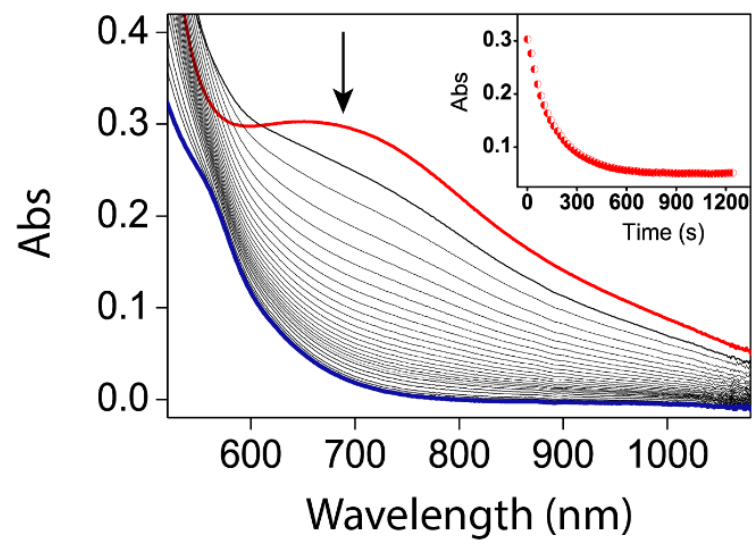

(a)

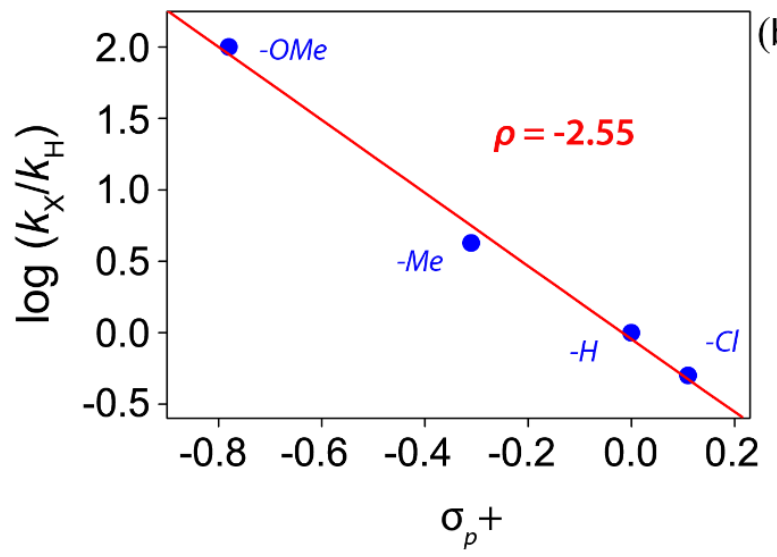

Fig. 2. (a) Decay profile for the $750 \mathrm{~nm}$ band due to addition of 150 equiv. of thioanisole to 4 in $\mathrm{CH}_{3} \mathrm{CN}$ at $298 \mathrm{~K}$; inset shows the time trace corresponding to the same decay. (b) Hammett plot obtained by plotting the $\log \left(\mathrm{k}_{\mathrm{x}} / \mathrm{k}_{\mathrm{H}}\right)$ values against the $\sigma_{p}{ }^{+}$Hammett values of para- $\mathrm{X}$-thioanisole $\left(\mathrm{X}=\mathrm{OMe}, \mathrm{Me}, \mathrm{H}\right.$ and $\mathrm{Cl}$ ) substrates in their reaction with 4 in $\mathrm{CH}_{3} \mathrm{CN}$ at $298 \mathrm{~K}$
To understand the oxidative properties of complex $\mathbf{4}$, we decided to investigate its heteroatom transfer reactivity to thioanisole as the model substrate. As reported previously, complex 2, $\left[\mathrm{Fe}^{\mathrm{IV}} \text { (NTs)(N4Py) }\right]^{2+}$ is five times more reactive than its oxo counterpart 1. ${ }^{9}$ Surprisingly, in the case of Bntpen, an opposite trend was observed to that found for N4Py. Unlike N4Py, the NTs complex 4 reacts sluggishly with thioanisole with considerably lower rate constants than those seen for the corresponding oxo complex 3. ${ }^{9}$ The second-order rate constant for the reaction of 4 with thioanisole was $5.4 \times 10^{-2} \mathrm{M}^{-1} \mathrm{~s}^{-1}$ at $298 \mathrm{~K}$, whereas for the same reaction with 2 , a value of $26 \times 10^{-}$ ${ }^{2} \mathrm{M}^{-1} \mathrm{~s}^{-1}$ was reported at $273 \mathrm{~K} .{ }^{9}$ Thus the rate of the reaction for 4 is expected to be even slower at $273 \mathrm{~K}$, although we were not able to record it at that temperature due to solubility issues. The slower reaction rate of $\mathbf{4}$ with thioanisole is, therefore, speculated to originate from a group transfer reaction instead of an electron transfer mechanism.

In order to establish the mechanism with conviction, we repeated the reaction using various para-substituted thioanisole substrates at $298 \mathrm{~K}$. The second order rate constants were plotted against the para-substituent constant $\left(\sigma_{p}\right)$ for each substrate to obtain a Hammett plot (Table 1 ). ${ }^{17} \mathrm{~A}$ large negative slope $\rho=-4.13$ is found, which is indicative of an electron transfer reaction (see Fig. S7, Electronic Supplementary Information). This value is larger than the one for N4Py where a negative slope of -3.36 has been reported corresponding to electron transfer reaction. ${ }^{9 a}$ Thus the parasubstituents on the thioanisole substrates contribute with quite a substantial effect on the rates of the reactions for 4 .

Table 1. Hammett parameters and second-order rate constants $\left(k_{2}\right)$ determined in the reaction of 4 ( $1 \mathrm{mM}$ solution in $\mathrm{CH}_{3} \mathrm{CN}$ ) with various para-substituted thioanisole substrates in $\mathrm{CH}_{3} \mathrm{CN}$ at $298 \mathrm{~K}^{\text {a }}$

\begin{tabular}{cccccc}
\hline$p-X$ & $\sigma_{p}{ }^{b}$ & $\sigma_{p}{ }^{b}$ & $k_{2}\left(\mathrm{M}^{-1} \mathbf{s}^{-1}\right)$ & $k_{\mathrm{x}} / k_{\mathrm{H}}{ }^{c}$ & $\log \left(k_{\mathrm{x}} / k_{\mathrm{H}}\right)$ \\
\hline$-\mathrm{OMe}$ & -0.27 & -0.78 & $541.4 \times 10^{-2}$ & 100.3 & 2.00 \\
\hline$-\mathrm{Me}$ & -0.17 & -0.31 & $22.9 \times 10^{-2}$ & 4.2 & 0.63 \\
\hline$-\mathrm{H}$ & 0.00 & 0.00 & $5.4 \times 10^{-2}$ & 1.0 & 0.00 \\
\hline$-\mathrm{Cl}$ & 0.23 & 0.11 & $2.7 \times 10^{-2}$ & 0.5 & -0.30 \\
\hline
\end{tabular}

${ }^{a}$ All the reactions were followed by monitoring the UV/Vis spectral changes of the reaction solution. ${ }^{b}$ Data taken from: H. C. Brown and Y. Okamoto, J. Am. Chem. Soc., $1958,80,4979$. ' Relative rate constant obtained by dividing the $k_{2}$ of $p$-Xthioanisole by $k_{2}$ of $p$-H-thioanisole.

This huge slope in the Hammett plot implicates an additional stabilization of positive charge in the transition state by electron-donating groups in the para-position of thioanisole and thus enhances the overall rate of the reaction when methoxy or methyl groups are employed. Therefore, the $\sigma_{p}$ values for the barrier heights for the reaction of parasubstituted thioanisole with $\left[\mathrm{Fe}^{\mathrm{IV}}(\mathrm{NTS})(\text { Bntpen) }]^{2+}\right.$ are insufficiently negative for electron-rich para-substituents. In order to accommodate this effect, the Hammett plot was replotted using $\sigma_{p}{ }^{+}$on the $\mathrm{x}$-axis instead, where the scale is shifted to further negative values of the substituent constants and thereby produces a better fitting. Thus, a $\rho$ value of -2.55 
was obtained (see Fig. 2b) with a better fitting correlation to the experimental data. Complex $\mathbf{2}$, in comparison, produced a negative slope of -1.92 when the rates were plotted against $\sigma_{p}{ }^{+} .{ }^{9 a}$ Nevertheless, these values from the Hammett plots for $\mathbf{4}$ are substantial evidence of an operating electron transfer mechanism in spite of slower reaction rates than the fellow tosylimido complex 2.

The iron(IV)-tosylimido complexes are usually weaker oxidants then their corresponding iron(IV)-oxo counterparts towards C$\mathrm{H}$ abstraction reactions and often cannot react with substrates with sacrificial $\mathrm{C}-\mathrm{H}$ bond dissociation energies (BDE) larger than $\sim 80 \mathrm{kcal} \mathrm{mol}^{-1}$. By contrast, the iron(IV)-oxo species of both Bntpen and N4Py are known to react with cyclohexane (BDE = $\left.99 \mathrm{kcal} \mathrm{mol}^{-1}\right)^{16 b, 26,27}$ by hydrogen atom abstraction. We tested the alcohol oxidation reactivity of $\mathbf{4}$ using benzyl alcohol as the model substrate, (see Fig. 3 ) and compared the results with the other oxidants. However, In the case of benzyl alcohol, the activation of the methylene $\mathrm{C}-\mathrm{H}$ bond by 4 was investigated at $298 \mathrm{~K}$ and led to the formation of benzaldehyde although at a slower rate compared to the analogous $\left[\mathrm{Fe}^{\mathrm{IV}}(\mathrm{NTS})(\mathrm{N} 4 \mathrm{Py})\right]^{2+}$ complex. While the second-order rate constant for benzyl alcohol oxidation by 2 was reported to be $1.48 \times 10^{-2} \mathrm{M}^{-1} \mathrm{~s}^{-1}$ the same reaction with 4 as oxidant revealed a second-order rate constant of $0.39 \times 10^{-2} \mathrm{M}^{-1} \mathrm{~s}^{-1}$ at $298 \mathrm{~K}$ (Fig. 3a)..${ }^{\text {gb }}$ Thus the iron(IV)-tosylimido complex of Bntpen reacts even slower with substrates than the one with N4Py ligand.

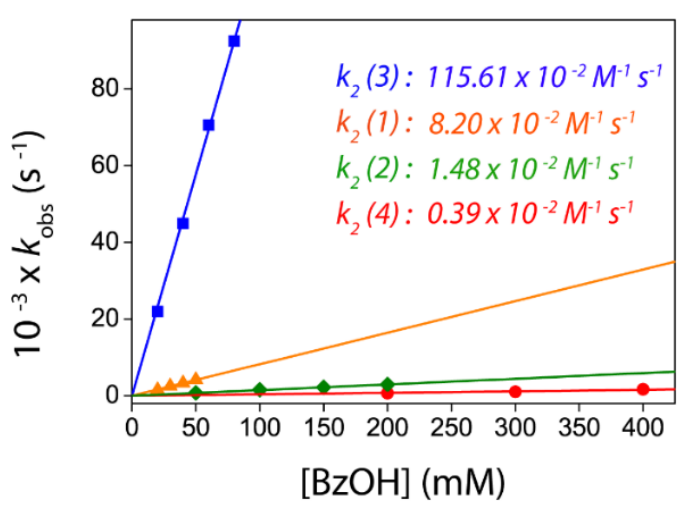

(a)

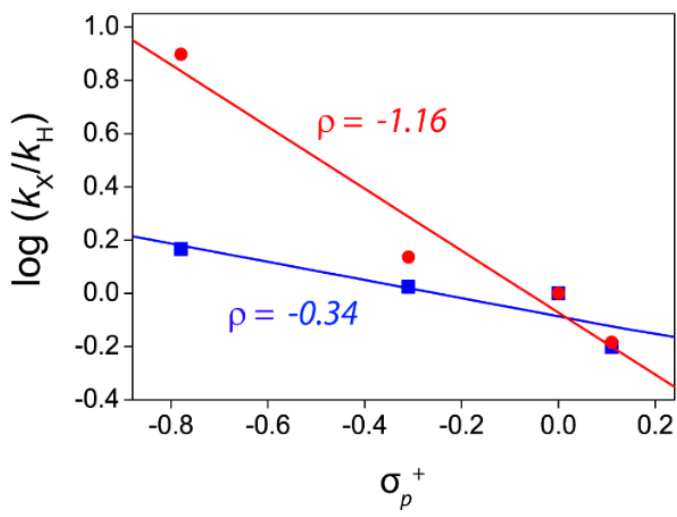

(b)

Fig. 3. (a) Second-order rate constants determined for the reaction of benzyl alcoho (BzOH) with $\mathbf{1}(\Delta), \mathbf{2}(\bullet), \mathbf{3}(\mathbf{\square})$ and $\mathbf{4}(\bullet)$ in $\mathrm{CH}_{3} \mathrm{CN}$ at $298 \mathrm{~K}$. (b) Hammett plot obtained by plotting the $\log \left(\mathrm{k}_{\mathrm{X}} / \mathrm{k}_{\mathrm{H}}\right)$ against ${\sigma_{\mathrm{p}}}^{+}$values of para-X-benzyl alcohol $(\mathrm{X}=\mathrm{OMe}, \mathrm{Me}, \mathrm{H}$ and $\mathrm{Cl}$ ) substrates (200 equiv.) in their reaction with $\mathbf{3}(\mathbf{\square})$ and $\mathbf{4}(\bullet)$ in $\mathrm{CH}_{3} \mathrm{CN}$ at $298 \mathrm{~K}$.
A comparison of the $[\mathrm{Fe}(\mathrm{O})(\mathrm{Bntpen})]^{2+} \quad(3)$ and $\left[\mathrm{Fe}(\mathrm{NTs})(\text { Bntpen) }]^{2+}(\mathbf{4})\right.$ complexes shows that 4 reacts 300 times slower than complex $\mathbf{3}$ under comparable reaction conditions. Thus, as compiled in Fig. 3 , the $\left[\mathrm{Fe}^{\mathrm{IV}}(\mathrm{O})(\text { Bntpen) }]^{2+}\right.$ complex (3) is 14 times more reactive than the $\left[\mathrm{Fe}^{\mathrm{IV}}(\mathrm{O})(\mathrm{N} 4 \mathrm{Py})\right]^{2+}$ complex (1), whereas, the $\left[\mathrm{Fe}^{\mathrm{IV}}(\mathrm{NTS})(\text { Bntpen) }]^{2+}\right.$ complex (4) is four times slower than the $\left[\mathrm{Fe}^{\mathrm{IV}}(\mathrm{NTS})(\mathrm{N} 4 \mathrm{Py})\right]^{2+}$ complex (2) towards an alcohol oxidation reaction. ${ }^{6}$

Kinetic isotope effect (KIE) studies were performed on $\mathbf{4}$ using benzyl alcohol-[ $\left[\mathrm{D}_{7}\right]$ as a substrate and a KIE value of 4 was obtained (see Fig. S8, Electronic Supplementary Information). Hence, the KIE experiment reveals hydrogen atom abstraction as the rate determining step in the reaction mechanism. A similar KIE value of 7 was obtained for complex 2, which suggests an analogous reaction mechanism. ${ }^{\text {gb }}$ Unlike the iron(IV)-tosylimido group, the corresponding iron(IV)-oxo complexes produce higher KIE values, probably due to tunnelling like mechanism. ${ }^{9}$ To ascertain the effect of intrinsic parameters including electron donating or withdrawing groups on the reacting substrate, we repeated the reactions using 200 equivalents of para-OMe, $-\mathrm{Me},-\mathrm{H}$ and $-\mathrm{Cl}$ substituents of benzyl alcohol. The reaction of $\mathbf{4}$ with each of these substrates follows pseudo first-order kinetics, as excess amounts (200 equiv.) of substrate concentrations were employed to obtain the pseudo first-order rate constant ( $k_{\text {obs }}$ ) values (Table 2 ).

Table 2. Hammett parameters and pseudo first-order rate constants $\left(k_{\mathrm{obs}}\right)$ determined in the reaction of $4(1 \mathrm{mM})$ with various para-substituted benzyl alcohols $(300 \mathrm{mM})$ in $\mathrm{CH}_{3} \mathrm{CN}$ at $298 \mathrm{~K}^{\text {. }}$

\begin{tabular}{cccccc}
\hline $\boldsymbol{p}-\mathrm{X}$ & $\boldsymbol{\sigma}_{p}{ }^{b}$ & $\boldsymbol{\sigma}_{p}{ }^{+b}$ & $\begin{array}{c}\boldsymbol{k}_{\mathrm{obs}}\left(\mathbf{s}^{-\mathbf{1}}\right) \mathbf{x} \\
\mathbf{1 0}^{-4}\end{array}$ & $\boldsymbol{k}_{\mathrm{x}} / \boldsymbol{k}_{\mathrm{H}}{ }^{c}$ & $\log \left(\boldsymbol{k}_{\mathrm{x}} / \boldsymbol{k}_{\mathrm{H}}\right)$ \\
\hline$-\mathrm{OMe}$ & -0.27 & -0.78 & 57.40 & 7.90 & 0.89 \\
\hline$-\mathrm{Me}$ & -0.17 & -0.31 & 9.94 & 1.37 & 0.14 \\
\hline$-\mathrm{H}$ & 0.00 & 0.00 & 7.26 & 1.00 & 0.00 \\
\hline$-\mathrm{Cl}$ & 0.23 & 0.11 & 4.76 & 0.65 & -0.18 \\
\hline
\end{tabular}

${ }^{a}$ All the reactions were followed by monitoring the UV/Vis spectral changes of the reaction solution. ${ }^{b}$ Data taken from: H. C. Brown and Y. Okamoto, J. Am. Chem. Soc., $1958,80,4979 .{ }^{c}$ Relative rate constant obtained by dividing the $k_{\text {obs }}$ of $p$-Xbenzyl alcohol by $k_{\text {obs }}$ of $p-\mathrm{H}$ - benzyl alcohol.

A Hammett plot of the natural logarithm of the rate constant ratio of para-X-benzyl alcohol activation versus benzyl alcohol against $\sigma_{p}+$ Hammett parameter gives a $\rho$ value of -1.16 for 4 which is close to the value reported above for complex $\mathbf{2}$ (Fig. 3b). ${ }^{9 b}$ This Hammett value is indicative of substantial positive charge build-up in the transition state. Therefore, the reaction rates are strongly affected by tuning the electronic charge content in the reacting substrates during the transition state. Other hydrocarbon substrates viz. xanthene, 9,10dihydroanthracene (DHA) and fluorene, were tested for $\mathrm{C}-\mathrm{H}$ abstraction reactions using $\mathbf{4}$ as the catalyst in order to envisage a comparative trend with complex $\mathbf{2}$. However, those reaction results were not pertinent due to solubility issues in $\mathrm{CH}_{3} \mathrm{CN}$. 


\section{ARTICLE}

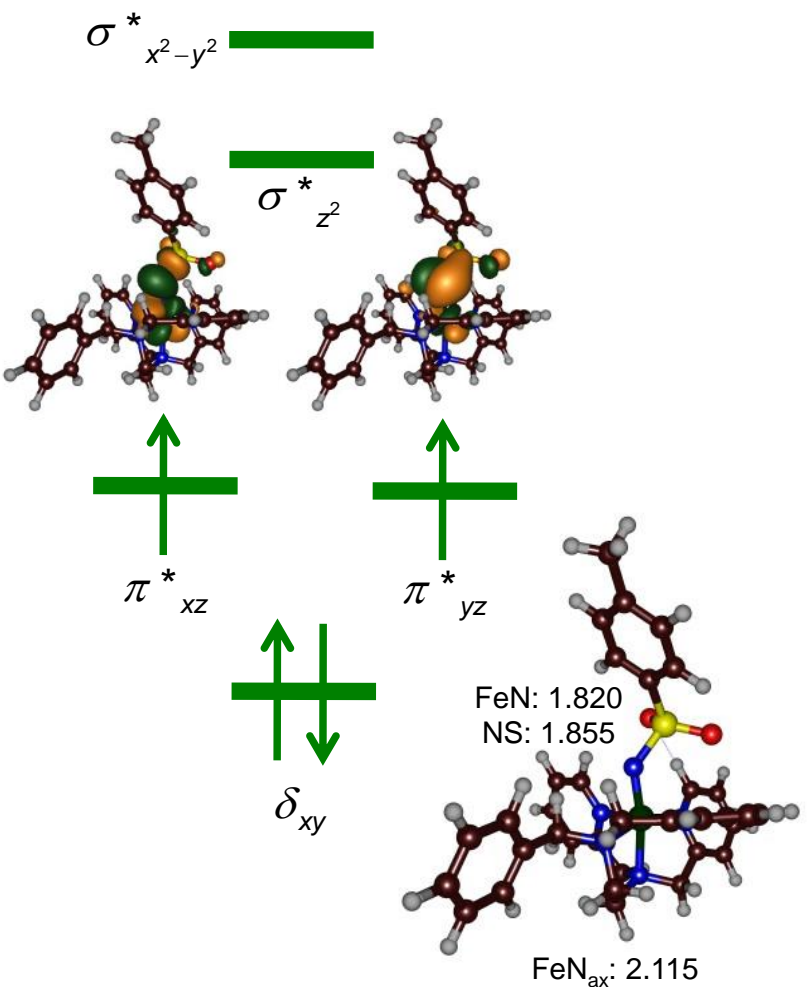

$\left[\mathrm{Fe}^{\mathrm{IV}}(\mathrm{NTs})(\text { Bntpen) }]^{2+}\right.$

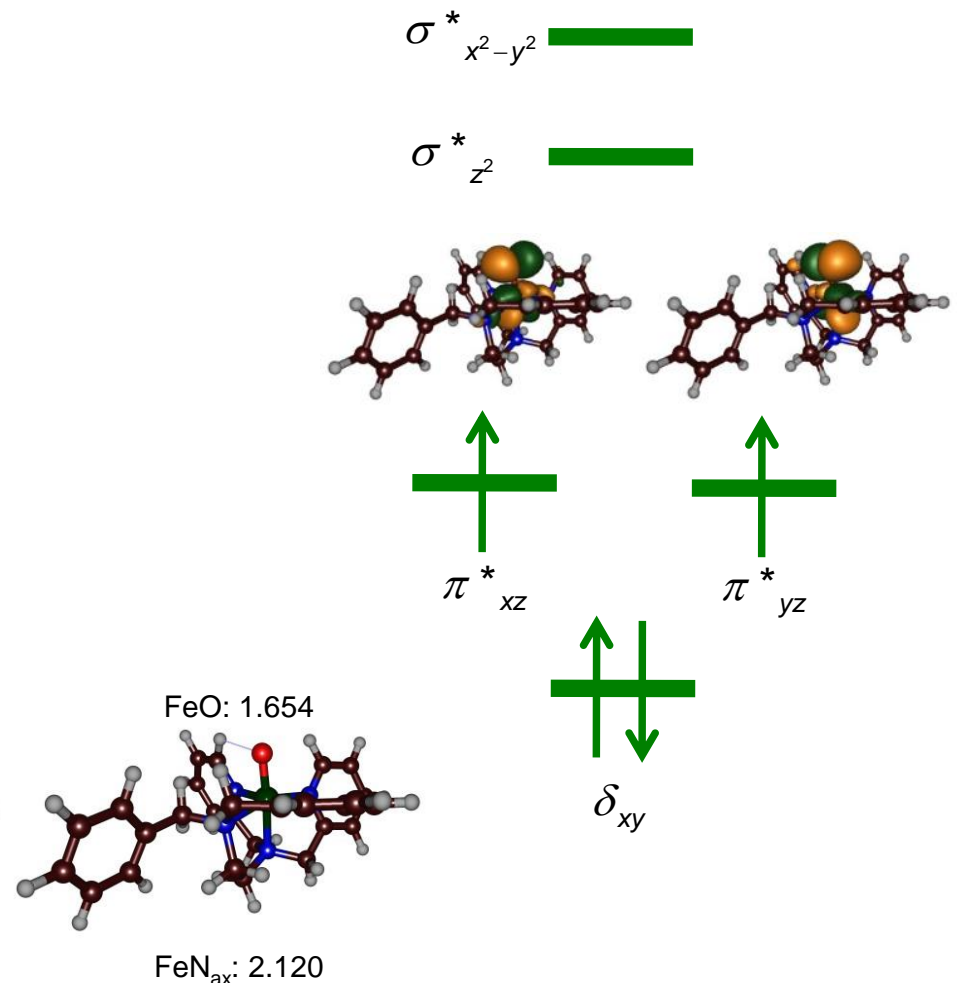

$\left[\mathrm{Fe}^{\mathrm{IV}}(\mathrm{O})(\text { Bntpen })\right]^{2+}$

Fig. 4. Optimized geometries and molecular orbital occupation of $\left[\mathrm{Fe}^{\mathrm{IV}}(\mathrm{NTS})(\text { Bntpen })\right]^{2+}$ and $\left[\mathrm{Fe}^{\mathrm{IV}}(\mathrm{O})(\mathrm{Bntpen})\right]^{2+}$ as obtained with DFT. Bond lengths are in angstroms.

Therefore, unlike the $\left[\mathrm{Fe}^{\mathrm{IV}}(\mathrm{NTS})(\mathrm{N} 4 \mathrm{Py})\right]^{2+}$ (2) complex, the $\left[\mathrm{Fe}^{\mathrm{IV}}(\mathrm{NTS})(\text { Bntpen })\right]^{2+}$ (4) is a less effective oxidant than its corresponding iron(IV)-oxo analogue in both the heteroatom amination and $\mathrm{C}-\mathrm{H}$ abstraction reactions.

To complement our understanding on the reactivity differences of $\left[\mathrm{Fe}^{\mathrm{IV}}(\mathrm{X})(\text { Bntpen })\right]^{2+}$ vs $\left[\mathrm{Fe}^{\mathrm{IV}}(\mathrm{X})(\mathrm{N} 4 \mathrm{Py})\right]^{2+}$ with $\mathrm{X}=\mathrm{NTs} / \mathrm{O}$, we performed a density functional theory study with 1,3cyclohexadiene (CHD) and dimethylsulfide (DMS) as model substrates. CHD dehydrogenation is a stepwise process with two sequential hydrogen atom abstraction steps (via transition states $\mathbf{T S} \mathbf{1}_{\mathrm{CHD}}$ and $\mathbf{T S} \mathbf{2}_{\mathrm{CHD}}$ ) that passes a radical intermediate (IR1 $1_{\mathrm{CHD}}$ ) to ultimately form the benzene product ( $\mathbf{P r d}_{\mathrm{CHD}}$ ). Heteroatom transfer (NTs or O) to sulphide is a concerted reaction with a single transition state ( $\mathrm{TS}_{\mathrm{DMS}}$ ) leading to products ( Prd $_{\mathrm{DMS}}$ ).

Before going into detail of the reaction mechanisms with substrates, let us first look into the electronic properties of the iron(IV)-oxo and iron(IV)-imido reactants with Bntpen ligand system. Thus, the high-lying occupied and low-lying virtual orbitals of $\left[\mathrm{Fe}^{\mathrm{IV}}(\mathrm{NTs})(\mathrm{Bntpen})\right]^{2+}$ and $\left[\mathrm{Fe}^{\mathrm{IV}}(\mathrm{O})(\text { Bntpen) }]^{2+}\right.$ and the optimized geometries are given in $\mathrm{Fig} 4$. In both $\left[\mathrm{Fe}^{\mathrm{IV}}(\mathrm{NTs})(\text { Bntpen })\right]^{2+}$ and $\left[\mathrm{Fe}^{\mathrm{IV}}(\mathrm{O})(\text { Bntpen })\right]^{2+}$ the triplet spin state is the ground state, which matches experimental studies as well as previous DFT calculations. ${ }^{8 a, 27,28}$ For both structures, the high-lying valence orbitals are dominated by the metal $3 d$ orbitals and their interactions in the first-coordination sphere. The metal $3 \mathrm{~d}$ orbitals split into a low-lying $\delta_{\mathrm{xy}}$ orbital in the plane of the three pyridine nitrogen atoms of Bntpen, two higher lying $\pi^{*}$ orbitals for the antibonding interaction along the $\mathrm{Fe}-\mathrm{O}$ bond $\left(\pi^{*}{ }_{x z}\right.$ and $\left.\pi^{*}{ }_{y z}\right)$ and two $\sigma$-type antibonding orbitals $\left(\sigma^{*}{ }_{z 2}\right.$ and $\left.\sigma^{*} \times 2-y 2\right)$. The latter two orbitals are the antibonding interactions along the $\mathrm{O}-\mathrm{Fe}-\mathrm{N}_{\text {axial }}$ axis and the ones in the $x y$-plane of the metal with the three pyridine nitrogen atoms.

The five metal $3 d$-orbitals are occupied with four electrons and the lowest energy conformation is the triplet spin state with $\delta_{x y}{ }^{2}$ $\pi^{*}{ }_{\mathrm{xz}}{ }^{1} \pi^{*}{ }_{\mathrm{yz}}{ }^{1}$ occupation (Fig. 4). This is commonly seen in 


\section{ARTICLE}

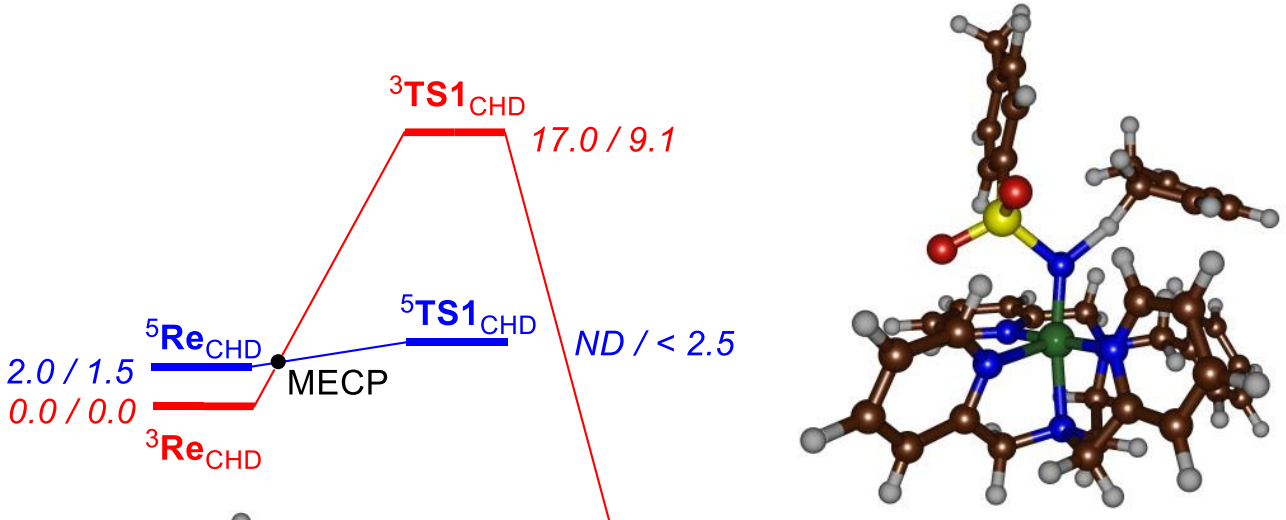

${ }^{3} \mathrm{TS} \mathbf{1}_{\mathrm{CHD}}$

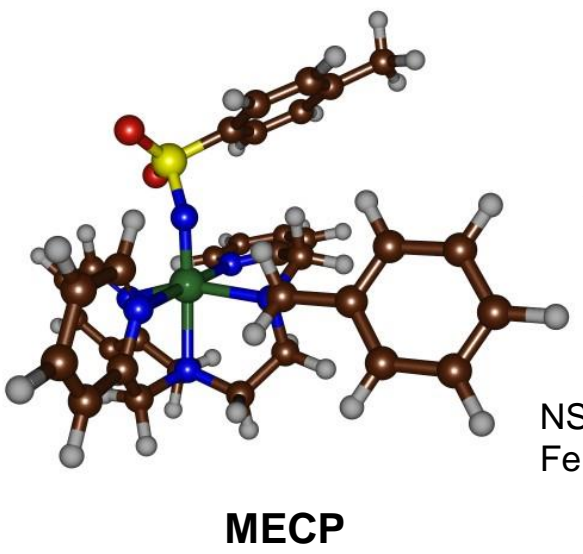

NS: 1.668

FeN: 1.705

MECP
$\mathrm{CH}: 1.271 / 1.217$

$\mathrm{XH}: 1.544 / 1.464$

$X S: 1.858$

FeX: $1.852 / 1.747$

$\mathrm{i} 842 / \mathrm{i} 493 \mathrm{~cm}^{-1}$

Fig 5. UB3LYP/BS2//UB3LYP/BS1 calculated reaction mechanism for CHD activation by [Fe $\left.{ }^{\mathrm{IV}}(\mathrm{NTS})(\mathrm{Bntpen})\right]^{2+} /\left[\mathrm{Fe}^{\mathrm{IV}}(\mathrm{O})(\mathrm{Bntpen})\right]^{2+}$. Energies obtained at UB3LYP/BS2//UB3LYP/BS1 and contain zero-point and solvent corrections (in $\mathrm{kcal} \mathrm{mol}^{-1}$ ). Optimized geometries of the transition states and MECP give distances in angstroms and the imaginary frequencies are in $\mathrm{cm}^{-1}$

hexacoordinated iron(IV)-oxo species and matches previous computational studies on nonheme iron complexes. ${ }^{29}$ The alternative quintet spin state has orbital occupation $\delta_{\mathrm{xy}}{ }^{1} \pi^{*}{ }_{\mathrm{xz}}{ }^{1}$ $\pi^{*}{ }_{\mathrm{yz}}{ }^{1} \sigma^{*}{ }_{\mathrm{x} 2-\mathrm{yz}}{ }^{1}$. This state is $\Delta \mathrm{E}+\mathrm{ZPE}=2.0 \mathrm{kcal}^{\mathrm{mol}}{ }^{-1}$ higher in energy than the triplet spin state for the iron(IV)-tosylimido complex, whereas in the iron(IV)-oxo species it is higher by 1.5 $\mathrm{kcal} \mathrm{mol}^{-1}$. As such, the change from oxo to tosylimido in the iron(IV)-Bntpen complex has little effect on the spin state ordering and relative energies.

There are several weak interactions of $\mathrm{C}-\mathrm{H}$ groups that donate a hydrogen bonding interaction to the oxo group, but this has little effect on the orbital shapes and contributions. The optimized geometries of ${ }^{3}\left[\mathrm{Fe}^{\mathrm{IV}}(\mathrm{NTs})(\text { Bntpen) }]^{2+}\right.$ and ${ }^{3}\left[\mathrm{Fe}^{\mathrm{IV}}(\mathrm{O})(\text { Bntpen })\right]^{2+}$ match previously reported results well. In both structures the distal atom is close to the centre of the four nitrogen atoms of the Bntpen group and the metal binds the axial nitrogen atom $\left(\mathrm{N}_{\mathrm{ax}}\right)$ at a distance of about $2.12 \AA$. The

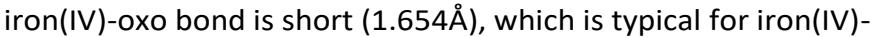
oxo complexes in six-coordinate nonheme and heme biomimetic model complexes. ${ }^{29,30}$ By contrast, the $\mathrm{Fe}-\mathrm{N}$ bond in the iron(IV)-tosylimido structure is much longer (1.820A) despite the same orbital occupation.

Next, we explored the dehydrogenation of cyclohexadiene (CHD) by both complexes and the results are given in Fig. 5 . We located transition state structures for the triplet spin surface; however, on the quintet spin state the transition from reactants to intermediates is facile and no barrier could be located. In the triplet spin state reaching the radical intermediate is an exergonic process by $-17.0 /-16.2 \mathrm{kcal} \mathrm{mol}^{-1}$ for 


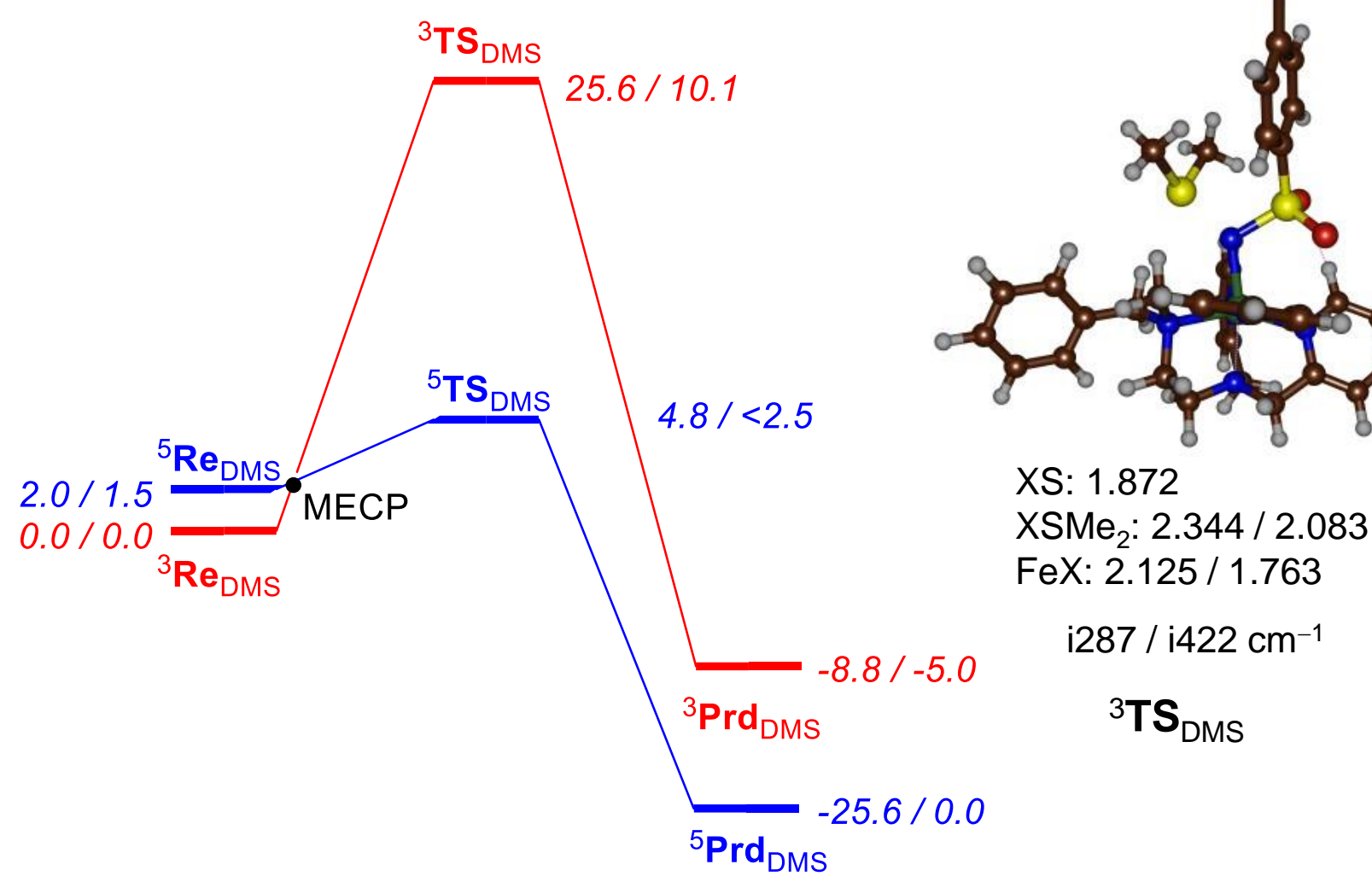

Fig. 6. UB3LYP/BS2//UB3LYP/BS1 calculated reaction mechanism for DMS activation by [Fe ${ }^{\mathrm{IV}}(\mathrm{NTS})(\text { Bntpen) }]^{2+} /\left[\mathrm{Fe}^{\mathrm{IV}}(\mathrm{O})(\mathrm{Bntpen})\right]^{2+}$. Energies obtained at UB3LYP/BS2//UB3LYP/BS1 and contain zero-point and solvent corrections (in $\mathrm{kcal} \mathrm{mol}^{-1}$ ). Optimized geometries of the transition states give distances in angstroms and the imaginary frequencies are in $\mathrm{cm}^{-1}$.

$\left[\mathrm{Fe}^{\mathrm{IV}}(\mathrm{NTs})(\text { Bntpen })\right]^{2+}$ versus $\left[\mathrm{Fe}^{\mathrm{IV}}(\mathrm{O})(\text { Bntpen })\right]^{2+}$. In the next step a second hydrogen atom abstraction takes place, which is facile and leads to products with large exothermicity. As such on the triplet spin state surface the initial hydrogen atom abstraction is rate-determining. The transition state is shown in Fig. 5 and displays an early structure with short $\mathrm{C}-\mathrm{H}$ distance of $1.271 \AA$ and a much longer $\mathrm{N}-\mathrm{H}$ distance of $1.544 \AA$. Interestingly, the transition state for the iron(IV)-oxo species in the triplet spin state is very similar with a $\mathrm{C}-\mathrm{H}$ distance of $1.217 \AA$ and an $\mathrm{O}-\mathrm{H}$ distance of $1.464 \AA$. Energetically; however, they are very different and ${ }^{3} \mathbf{T S} 1_{\mathrm{CHD}, \mathrm{NTs}}$ is $17.0 \mathrm{kcal} \mathrm{mol}^{-1}$ above reactants, while the corresponding iron-oxo transition state only has a barrier of $9.1 \mathrm{kcal} \mathrm{mol}^{-1}$.

Nevertheless, the landscape in Fig 5 shows that even though the reactant structure is a triplet spin, the rest of the landscape is lower lying on the quintet spin state surface. To find out if a spin-state crossing would be possible, we calculated the minimum energy crossing points, MECP, from triplet to quintet. We located the MECPs close in energy to the triplet-quintet energy gap in the reactants, i.e. within $1 \mathrm{kcal} \mathrm{mol}^{-1}$ for $\left[\mathrm{Fe}^{\mathrm{IV}}(\mathrm{NTs})(\text { Bntpen) }]^{2+},\left[\mathrm{Fe}^{\mathrm{IV}}\right.\right.$ (NTs)(N4Py) ${ }^{2+}$ and $\left[\mathrm{Fe}^{\mathrm{IV}}(\mathrm{O})(\mathrm{N} 4 \mathrm{Py})\right]^{2+}$, whereas for $\left[\mathrm{Fe}^{\mathrm{IV}}(\mathrm{O})(\mathrm{Bntpen})\right]^{2+}$ the MECP was found at +4.9 $\mathrm{kcal} \mathrm{mol}^{-1}$ above the triplet spin ground state. As such, for all four profiles, we expect a fast and efficient spin state crossing from the triplet to the quintet spin state surface. Moreover, the reaction will be dominated by the spin-state crossing from triplet to quintet and its probability will determine the reaction rate, and consequently, will determine the rate constant of the reaction. The optimized MECP structure for the mechanisms starting with $\left[\mathrm{Fe}^{\mathrm{IV}}(\mathrm{NTs})(\text { Bntpen) }]^{2+}\right.$ is shown in Fig. 5. The MECP 
is close to the reactant complexes and has optimized Fe-N and $\mathrm{N}-\mathrm{S}$ distances in between those of triplet and quintet spin reactants.

Next, we evaluated substrate sulfoxidation by using DMS as a model substrate. As before, the reaction is concerted via a single intermediate to give sulfoxide products. ${ }^{31}$ Similarly to the hydrogen atom abstraction process in Fig 5 , also sulfoxidation has a high energy barrier on the triplet spin state $\left(25.6 \mathrm{kcal} \mathrm{mol}^{-}\right.$ 1) for the $\left[\mathrm{Fe}^{\mathrm{IV}}(\mathrm{NTs})(\text { Bntpen) }]^{2+}\right.$ oxidant, while it is much lower for the $\left[\mathrm{Fe}^{\mathrm{IV}}(\mathrm{O})(\text { Bntpen) }]^{2+}\right.$ system at $10.1 \mathrm{kcal}^{\mathrm{mol}}{ }^{-1}$. The transition state structures shown in Fig 6 display a long $\mathrm{N}-\mathrm{S}$ distance between tosylimido and substrate of $2.344 \AA$, while the iron-oxo system has the transition state at a distance of $2.083 \AA$ In addition, the imaginary frequency in the transition state is large for the oxo-transfer (i422 $\mathrm{cm}^{-1}$ ), while tosylimido transfer gives an imaginary frequency of only i287 $\mathrm{cm}^{-1}$. These relative barriers contrast those found for the analogous N4Py system, ${ }^{9 b}$ that found faster reactivity with sulfides for the iron(IV)tosylimido complex.

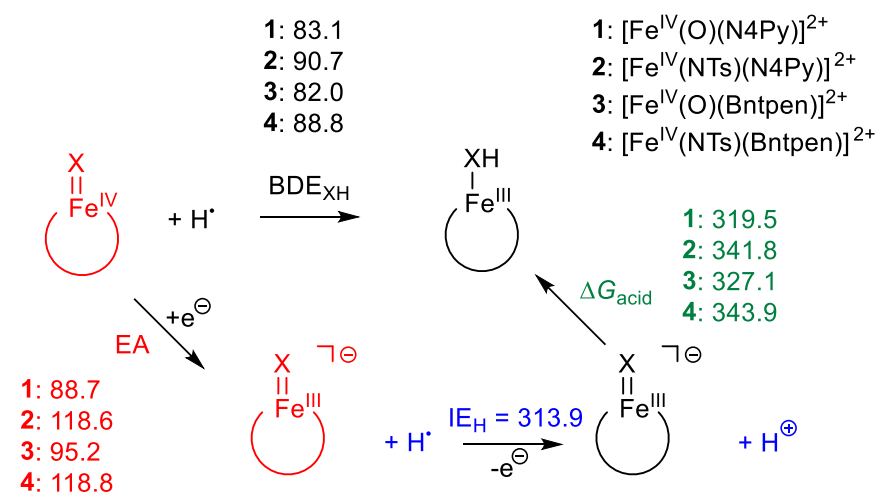

Fig. 7. Thermochemical reaction energies $\left(\triangle E+Z P E\right.$ data in $\left.\mathrm{kcal}^{\mathrm{mol}}{ }^{-1}\right)$ for the various iron(IV)-toylimido and iron(IV)-oxo species studied in this work.

To understand the differences in properties and reactivity of the four set of oxidants investigated here, i.e. [Felv(NTs)(Bntpen) $]^{2+}$, $\left[\mathrm{Fe}^{\mathrm{IV}}(\mathrm{O})(\text { Bntpen) }]^{2+},\left[\mathrm{Fe}^{\mathrm{IV}}(\mathrm{NTs})(\mathrm{N} 4 \mathrm{Py})\right]^{2+}\right.$ and $\left[\mathrm{Fe}^{\mathrm{IV}}(\mathrm{O})(\mathrm{N} 4 \mathrm{Py})\right]^{2+}$ we calculated the thermochemical properties of each of these reactant species. Firstly, we calculated the $X-H(X=N T s / O)$ bond dissociation energy $\left(\mathrm{BDE}_{\mathrm{XH}}\right)$ as the difference in energy between the iron(IV)-oxo/iron(IV)-tosylimido species, a hydrogen atom and the corresponding iron(III)hydroxo/iron(III)-hydrotosylimido species. We also calculated the one-electron reduction potential or electron affinity (EA) as the adiabatic energy difference of the iron(IV)tosylimido/iron(IV)-oxo and the one-electron reduced species. As before, ${ }^{32}$ we calculated the gas-phase acidity $\left(\Delta G_{\text {acid }}\right)$ from the difference in $B D E_{X H}, E A$ and the ionization energy of a hydrogen atom $\left(I E_{H}\right)$ using the experimentally reported value of $\mathrm{IE}_{\mathrm{H}}=313.9 \mathrm{kcal} \mathrm{mol}^{-1} .{ }^{33}$ The calculated values for $\mathrm{BDE} \mathrm{EH}_{\mathrm{XH}}, \mathrm{EA}$ and $\Delta \mathrm{G}_{\text {acid }}$ of the four iron(IV) oxidants are given in Fig. 7. As can be seen the four $B D E_{X H}$ values range within a narrow window from $82.0 \mathrm{kcal} \mathrm{mol}^{-1}$ for the $\left[\mathrm{Fe}^{\mathrm{IV}}(\mathrm{O})(\text { Bntpen) }]^{2+}\right.$ species to $90.7 \mathrm{kcal}$ $\mathrm{mol}^{-1}$ for the $\left[\mathrm{Fe}^{\mathrm{IV}} \text { (NTs)(N4Py) }\right]^{2+}$ system. Nevertheless, the two iron(IV)-oxo species have similar BDE $\mathrm{XH}_{\mathrm{XH}}$ values and so do the pair of iron(IV)-tosylimido complexes. Based on this, similar hydrogen atom abstraction barriers from substrates for the pair of iron(IV)-oxo and iron(IV)-tosylimido complexes are expected.

\section{Conclusions}

In this work we present a combined experimental and computational study on the properties and reactivities of iron(IV)-oxo and iron(IV)-tosylimido complexes. In particular, we synthesize and spectroscopically characterize the iron(IV)tosylimido and iron(IV)-oxo complexes with the pentacoordinate ligand system, Bntpen, and compared with those of the existing N4Py framework. Its spectroscopic fingerprint shows similar features as the analogous N4Py ligated system, particularly in the UV/Vis spectrum. Subsequently, a series of reactivity studies with iron(IV)-oxo and iron(IV)tosylimido was done with respect to para-X-thioanisole and para-X-benzyl alcohol as substrate. Overall, the iron(IV)tosylimido complexes with Bntpen ligand are weaker oxidants for hydrogen atom abstraction and group transfer reactions than their corresponding iron(IV)-oxo species. We then did a computational study to support the experiments and find that generally the iron(IV)-tosylimido forms strong $\mathrm{N}-\mathrm{H}$ bonds after hydrogen atom abstraction but has a larger redox potential and therefore reacts slower with substrates.

\section{Conflicts of interest}

There are no conflicts to declare.

\section{Acknowledgements}

C.V.S. acknowledges research support provided by the Department of Science and Technology (SERB), India through grant code CRG/2019/000387. S.P.d.V. and C.V.S. thank the British Council for a UK-India Education and Research Initiative grant (grant code DST/INT/UK/P-151/2017). GM acknowledges Department of Science and Technology (SERB) for fellowship. We also thank Central Instrumentation Facility (CIF) IIT Guwahati for providing instrumental facilities. FGCR thanks the Conacyt Mexico for a studentship.

\section{Notes and references}

1 a) E. I. Solomon, T. C. Brunold, M. I. Davis, J. N. Kemsley, S.-K. Lee, N. Lehnert, F. Neese, A. J. Skulan, Y.-S. Yang and J. Zhou, Chem. Rev., 2000, 100, 235; b) T. D. H. Bugg, Curr. Opin. Chem. Biol., 2001, 5, 550; c) M. J. Ryle and R. P. Hausinger, Curr. Opin. Chem. Biol., 2002, 6, 193; d) M. Costas, M. P. Mehn, M. P. Jensen and L. Que Jr, Chem. Rev., 2004, 104, 939; e) B. Meunier, S. P. de Visser and S. Shaik, Chem. Rev., 2004, 104, 3947; f) K. M. Kadish, K. M. Smith and R. Guilard (Eds.), Handbook Of Porphyrin Science, World Scientific Publishing Co., New Jersey, 2010; g) X. Huang and J. T. Groves, Chem. Rev., 2018, 118, 2491.

2 a) B. K. Burgess and D. J. Lowe, Chem. Rev., 1996, 96, 2983; b) B. M. Hoffman, D. Lukoyanov, D. R. Dean and L. C. Seefeldt, 
Acc. Chem. Res., 2013, 46, 587; c) R. R. Eady, S. V. Antonyuk and S. S. Hasnain, Curr. Opin. Chem. Biol., 2016, 31, 103.

3 a) R. E. White and M. B. McCarthy, J. Am. Chem. Soc., 1984, 106, 4922; b) E. W. Svastits, J. H. Dawson, R. Breslow and S. H. Gellman, J. Am. Chem. Soc., 1985, 107, 6427; c) J.-P. Mahy, G. Bedi, P. Battioni and D. Mansuy, J. Chem. Soc. Perkin Trans. II, 1988, 1517; d) G. Sabenya, L. Lázaro, I. Gamba, V. MartinDiaconescu, E. Andris, T. Weyhermüller, F. Neese, J. Roithova, E. Bill, J. Lloret-Fillol and M. Costas, J. Am. Chem. Soc. 2017, 139, 9168.

4 a) J. C. Price, E. W. Barr, B. Tirupati, J. M. Bollinger Jr and C. Krebs, Biochemistry, 2003, 42, 7497; b) D. A. Proshlyakov, T. F. Henshaw, G. R. Monterosso, M. J. Ryle and R. P. Hausinger J. Am. Chem. Soc., 2004, 126, 1022; c) J. M. Bollinger Jr., J. C. Price, L. M. Hoffart, E. W. Barr and C. Krebs, Eur. J. Inorg. Chem., 2005, 4245.

5 a) M. Atanasov, P. Comba, S. Hausberg and B. Martin, Coord. Chem. Rev., 2009, 253, 2306; b) M. Costas, Coord. Chem. Rev. 2011, 255, 2912; c) C. V. Sastri, J. Lee, K. Oh, Y. J. Lee, J. Lee, T. A. Jackson, K. Ray, H. Hirao, W. Shin, J. A. Halfen, J. Kim, L. Que Jr., S. Shaik and W. Nam, Proc. Natl. Acad. Sci. USA, 2007, 104, $19181 ;$ d) C. Buron, K. Sénéchal-David, R. Ricoux, J.-P. Le Caër, V. Guérineau, P. Méjanelle, R. Guillot, C. Herrero, J.-P. Mahy and F. Banse, Chem. Eur. J., 2015, 21, 12188; e) X. Engelmann, I. Monte-Pérez and K. Ray, Angew. Chem. Int. Ed., 2016, 55 7632; f) K. Ray, F. F. Pfaff, B. Wang and W. Nam, J. Am. Chem. Soc., 2014, 136, 13942; f) A. R. McDonald and L. Que Jr, Coord. Chem. Rev., 2013, 257, 414; g) W. Nam, Y.-M. Lee and S. Fukuzumi, Acc. Chem. Res., 2014, 47, 1146.

6 a) M. R. Bukowski, K. D. Koehntop, A. Stubna, E. L. Bominaar, J. A. Halfen, E. Münck, W. Nam and L. Que Jr, Science, 2005, 310, 1000; b) J.-U. Rohde, J.-H. In, M. H. Lim, W. W. Brennessel, M. R. Bukowski, A. Stubna, E. Münck, W. Nam and L. Que Jr, Science, 2003, 299, 1037; c) M. Martinho, F. Banse, J.-F. Bartoli, T. A. Mattioli, P. Battioni, O. Horner, S. Bourcier and J.-J. Girerd, Inorg. Chem., 2005, 44, 9592; d) C. V. Sastri, M. S. Seo, M. J. Park, K. M. Kim and W. Nam, Chem. Commun., 2005, 1405.

7 a) C.-M. Che, V. K.-Y. Lo, C.-Y. Zhou and J.-S. Huang, Chem. Soc. Rev., 2011, 40, 1950; b) H. Lu and X. P. Zhang, Chem. Soc. Rev. 2011, 40, 1899; c) Z. Long and D. Liang, Chin. Science Bull., 2012, 57, 2352; d) M. J. Zdilla, J. L. Dexheimer and M. M. AbuOmar, J. Am. Chem. Soc., 2007, 129, 11505; e) J. J. Scepaniak, C. G. Margarit, J. N. Harvey and J. M. Smith, Inorg. Chem. 2011 50, 9508; f) Y. Liu, X. Guan, E. Lai-Ming Wong, P. Liu, J.-Sheng Huang and C.-Ming Che, J. Am. Chem. Soc. 2013, 135, 7194; g) G. Sabenya, I. Gamba, L. Gómez, M. Clémancey, J. R. Frisch, E. J. Klinker, G. Blondin, S. Torelli, L. Que Jr, V. MartinDiaconescu, J.-M. Latour, J. Lloret-Fillol and M. Costas, Chem. Sci. 2019, 10, 9513; h) M. Jaccob and G. Rajaraman, Dalton Trans. 2012, 41, 10430; i) E. Gouré, D. Senthilnathan, G. Coin, F. Albrieux, F. Avenier, P. Dubourdeaux, C. Lebrun, P. Maldivi and J.-M. Latour, Angew. Chem. Int. Ed. 2017, 56, 4305; j) W. Tsung Lee, R. A. Juarez, J. J. Scepaniak, S. B. Muñoz, D. A Dickie, H. Wang and J. M. Smith, Inorg. Chem. 2014, 53, 8425 k) J. J. Scepaniak, J. A. Young, R. P. Bontchev and J. M. Smith, Angew. Chem. Int. Ed. 2009, 48, 3158; I) J. Hohenberger, $\mathrm{K}$. Ray and K. Meyer, Nature Communications, 2012, 3:720.

8 a) E. J. Klinker, T. A. Jackson, M. P. Jensen, A. Stubna, G. Juhász, E. L. Bominaar, E. Münck and L. Que Jr, Angew. Chem. Int. Ed., 2006, 45, 7394; b) C.-M. Che, V. K.-Y. Lo, C.-Y.; Zhou and J.-S Huang, Chem. Soc. Rev., 2011, 40, 1950; c) H. Lu and X. P. Zhang, Chem. Soc. Rev., 2011, 40, 1899; d) M. J. Zdilla, J. L. Dexheimer and M. M. Abu-Omar, J. Am. Chem. Soc., 2007, 129, 11505; e) E. Gouré, F. Avenier, P. Dubourdeaux, O. Sénèque, F. Albrieux, C. Lebrun, M. Clémancey, P. Maldivi and J.-M. Latour, Angew. Chem. Int. Ed., 2014, 53, 1580.
9 a) A. K. Vardhaman, P. Barman, S. Kumar, C. V. Sastri, D. Kumar and S. P. de Visser, Angew. Chem. Int. Ed., 2013, 52, 12288; b) S. Kumar, A. S. Faponle, P. Barman, A. K. Vardhaman, C. V. Sastri, D. Kumar and S. P. de Visser, J. Am. Chem. Soc., 2014, 136, 17102.

10 a) A. C. McQuilken, Y. Jiang, M. A. Siegler and D. P. Goldberg, J. Am. Chem. Soc., 2012, 134, 8758; b) S. Sahu, L. R. Widger, M. G. Quesne, S. P. de Visser, H. Matsumura, P. MoënneLoccoz, M. A. Siegler and D. P. Goldberg, J. Am. Chem. Soc. 2013, 135, 10590; c) L. R. Widger, C. G. Davies, T. Yang, M. A. Siegler, O. Troeppner, G. N. L. Jameson, I. Ivanović-Burmazović and D. P. Goldberg, J. Am. Chem. Soc., 2014, 136, 2699; d) S. Sahu, M. G. Quesne, C. G. Davies, M. Derr, I. IvanovićBurmazović, M. A. Siegler, G. N. L. Jameson, S. P. de Visser and D. P. Goldberg, J. Am. Chem. Soc., 2014, 136, 13542; e) S. Sahu, B. Zhang, C. J. Pollock, M. Derr, C. G. Davies, A. M. Confer, I. Ivanović-Burmazović, M. A. Siegler, G. N. L. Jameson, C. Krebs and D. P. Goldberg, J. Am. Chem. Soc., 2016, 138, 12791; f) M. Mitra, H. Nimir, S. Demeshko, S. S. Bhat, S. O. Malinkin, M. Haukka, J. Lloret-Fillol, G. C. Lisensky, F. Meyer, A. A. Shteinman, W. R. Browne, D. A. Hrovat, M. G. Richmond, M. Costas and E. Nordlander, Inorg. Chem., 2015, 54, 7152; g S. Rana, A. Dey and D. Maiti, Chem. Commun., 2015, 51 14469; h) W. Rasheed, A. Draksharapu, S. Banerjee, V. G. Young Jr, R. Fan, Y. Guo, M. Ozerov, J. Nehrkorn, J. Krzystek, J. Telser and L. Que Jr, Angew. Chem. Int. Ed., 2018, 57, 9387; Angew. Chem., 2018, 130, 9531; i) G. Mukherjee, C. W. Z. Lee, S. S. Nag, A. Alili, F. G. Cantú Reinhard, D. Kumar, C. V. Sastri and S. P. de Visser, Dalton Trans., 2018, 47, 14945; j) S. Rana, J. P. Biswas, A. Sen, M. Clémancey, G. Blondin, J.-M. Latour, G Rajaraman and D. Maiti, Chem. Sci., 2018, 9, 7843; k) G. Mukherjee, A. Alili, P. Barman, D. Kumar, C. V. Sastri and S. P. de Visser, Chem. Eur. J., 2019, 25, 5086.

11 a) S. Hong, K. D. Sutherlin, A. K. Vardhaman, J. J. Yan, S. Park Y.-M. Lee, S. Jang, X. Lu, T. Ohta, T. Ogura, E. I. Solomon and W. Nam, J. Am. Chem. Soc., 2017, 139, 8800; b) S. Hong, X. Lu, Y.-M. Lee, M. S. Seo, T. Ohta, T. Ogura, M. Clémancey, P. Maldivi, J.-M. Latour, R. Sarangi and W. Nam, J. Am. Chem. Soc., 2017, 139, 14372.

12 R. Patra and P. Maldivi, J. Mol. Model., 2016, 22, 278.

13 A. K. Vardhaman, Y.-M. Lee, J. Jung, K. Ohkubo, W. Nam and S. Fukuzumi, Angew. Chem. Int. Ed., 2016, 55, 3709.

14 Purification of Laboratory Chemicals, ed. W. L. F. Armarego and D. D. Perrin, Pergamon Press, Oxford, 1997.

15 a) H. Saltzman, in Organic Syntheses, Vol. V (Eds: J. G. Sharefkin); Wiley, New York, 1973, pp. 658; b) S. Taylor, J. Gullick, P. McMorn, D. Bethell, P. C. Bulman Page, F. E. Hancock, F. King and G. J. Hutchings., J. Chem. Soc. Perkin Trans., 2001, 2, 1714.

16 a) L. Duelund, R. Hazell, C. J. McKenzie, L. Preuss Nielsen and H. Toftlund, J. Chem. Soc. Dalton Trans., 2001, 152; b) J. Kaizer, E. J. Klinker, N. Y. Oh, J.-U. Rohde, W. J. Song, A. Stubna, J. Kim, E. Münck, W. Nam and L. Que, Jr. J. Am. Chem. Soc., 2004, 126, 472; c) J.-U. Rohde, S. Torelli, X. Shan, M. H. Lim, E. J. Klinker, J. Kaizer, K. Chen, W. Nam and L. Que, Jr, J. Am. Chem. Soc., 2004, 126, 16750; d) E. J. Klinker, J. Kaizer, W. W. Brennessel, N. L. Woodrum, C. J. Cramer and L. Que Jr, Angew. Chem. Int. Ed., 2005, 44, 3690.

17 a) H. C. Brown and Y. Okamoto, J. Am. Chem. Soc., 1958, 80, 4979; b) C. Hansch, A. Leo and R. W. Taft, Chem. Rev., 1991, 91, 165; c) Y. Goto, T. Matsui, S. I. Ozaki, Y. Watanabe and S. Fukuzumi, J. Am. Chem. Soc., 1999, 121, 9497.

18 a) A. D. Becke, J. Chem. Phys., 1993, 98, 5648; b) C. Lee, W. Yang and R. G. Parr, Phys. Rev. B, 1988, 37, 785.

19 P. J. Hay and W. R. Wadt, J. Chem. Phys., 1985, 82, 270.

20 R. Krishnan, J. S. Binkley, R. Seeger and J. A. Pople, J. Chem. Phys., 1980, 72, 650. 
21 J. Tomasi, B. Mennucci and R. Cammi, Chem. Rev., 2005, 105 2999.

22 Gaussian 09, Revision D.01, M. J. Frisch, G. W. Trucks, H. B. Schlegel, G. E. Scuseria, M. A. Robb, J. R. Cheeseman, G. Scalmani, V. Barone, B. Mennucci, G. A. Petersson, H. Nakatsuji, M. Caricato, X. Li, H. P. Hratchian, A. F. Izmaylov, J. Bloino, G. Zheng, J. L. Sonnenberg, M. Hada, M. Ehara, K. Toyota, R. Fukuda, J. Hasegawa, M. Ishida, T. Nakajima, Y. Honda, O. Kitao, H. Nakai, T. Vreven, J. A. Montgomery, Jr., J. E. Peralta, F. Ogliaro, M. Bearpark, J. J. Heyd, E. Brothers, K. N. Kudin, V. N. Staroverov, R. Kobayashi, J. Normand, K. Raghavachari, A. Rendell, J. C. Burant, S. S. lyengar, J. Tomasi, M. Cossi, N. Rega, J. M. Millam, M. Klene, J. E. Knox, J. B. Cross, V. Bakken, C. Adamo, J. Jaramillo, R. Gomperts, R. E. Stratmann, O. Yazyev, A. J. Austin, R. Cammi, C. Pomelli, J. W. Ochterski, R. L. Martin, K. Morokuma, V. G. Zakrzewski, G. A. Voth, P. Salvador, J. J. Dannenberg, S. Dapprich, A. D. Daniels, Ö. Farkas, J. B. Foresman, J. V. Ortiz, J. Cioslowski, and D. J. Fox, Gaussian, Inc., Wallingford CT, 2009.

23 F. Neese, Orca - An ab initio, DFT and semiempirical SCF-MO package. Version 4.0.1, 2019.

24 J. N. Harvey, Phys. Chem. Chem. Phys., 2007, 9, 331.

25 S. Banerjee, W. Rasheed, R. Fan, A. Draksharapu, W. N. Oloo, Y. Guo and L. Que Jr., Chem. Eur. J., 2019, 25, 9608.

26 a) L. E. Friedrich, J. Org. Chem., 1983, 48, 3851; b) J. M. Mayer, Acc. Chem. Res., 1998, 31, 441.

27 a) M. Lubben, A. Meetsma, E. C. Wilkinson, B. Feringa and L. Que Jr., Angew. Chem. Int. Ed., 1995, 34, 1512; b) D. Wang, K. Ray, M. J. Collins, E. R. Farquhar, J. R. Frisch, L. Gómez, T. A. Jackson, M. Kerscher, A. Waleska, P. Comba, M. Costas and L. Que Jr., Chem. Sci., 2013, 4, 282.

28 a) D. Kumar, H. Hirao, L. Que Jr and S. Shaik, J. Am. Chem. Soc. 2005, 127, 8026; b) F. G. Cantú Reinhard, A. S. Faponle and S.
P. de Visser, J. Phys. Chem. A, 2016, 120, 9805; c) T. Z. H. Gani and H. J. Kulik, ACS Catal., 2018, 8, 975.

29 a) H. Hirao, D. Kumar, L. Que Jr and S. Shaik, J. Am. Chem. Soc., 2006, 128, 8590; b) S. P. de Visser, J. Am. Chem. Soc., 2006, 128, 9813; c) L. Bernasconi and E.-J. Baerends, Eur. J. Inorg. Chem., 2008, 1672; d) S. D. Wong, C. B. Bell III, L. V. Liu, Y. Kwak, J. England, E. E. Alp, J. Zhao, L. Que Jr and E. I. Solomon, Angew. Chem. Int. Ed., 2011, 50, 3215; e) S. F. Ye and F. Neese, Proc. Natl. Acad. Sci. USA, 2011, 108, 1228; f) R. Latifi, M. A. Sainna, E. V. Rybak-Akimova and S. P. de Visser, Chem. Eur. J., 2013, 19, 4058; g) A. Ansari, A. Kaushik and G. Rajaraman, J. Am. Chem. Soc., 2013, 135, 4235; h) F. G. Cantú Reinhard and S. P. de Visser, Chem. Eur. J., 2017, 23, 2935.

30 a) M. T. Green, J. Am. Chem. Soc., 1999, 121, 7939; b) S. P. de Visser, S. Shaik, P. K. Sharma, D. Kumar and W. Thiel, J. Am. Chem. Soc., 2003, 125, 15779; c) S. P. de Visser and L. S. Tan, J. Am. Chem. Soc., 2008, 130, 12961; d) Y. Wang, D. Kumar, C. L. Yang, K. Han and S. Shaik, J. Phys. Chem. B, 2007, 111, 7700; e) L. Ji, A. S. Faponle, M. G. Quesne, M. A. Sainna, J. Zhang, A. Franke, D. Kumar, R. van Eldik, W. Liu and S. P. de Visser, Chem. Eur. J., 2015, 21, 9083.

31 a) D. Kumar, S. P. de Visser, P. K. Sharma, H. Hirao and S. Shaik, Biochemistry, 2005, 44, 8148; b) D. Kumar, G. N. Sastry and S. P. de Visser, Chem. Eur. J., 2011, 17, 6196.

32 a) S. P. de Visser, D. Kumar, S. Cohen, R. Shacham and S. Shaik, J. Am. Chem. Soc., 2004, 126, 8362; b) S. P. de Visser, J. Am. Chem. Soc., 2010, 132, 1087; c) S. Ghafoor, A. Mansha and S. P. de Visser, J. Am. Chem. Soc., 2019, 141, 20278.

33 E. P. Hunter and S. G. Lias, NIST Chemistry Webbook, NIST Standard Reference Database, Number 69; Eds.: P. J. Linstrom and W. G. Mallard, National Institute of Standards and Technology: Gaithersburg MD, 20899, (retrieved 29 October 2019), http://webbook.nist.gov. 